\title{
Optimization of Process Technology for Popping of Sorghum
}

\author{
Kanifnath Nakade $^{1 *}$, Smita Khodke ${ }^{1}$, Avinash Kakade ${ }^{2}$ and Nilza Othzes ${ }^{3}$ \\ ${ }^{1}$ Department of Agriculture Process Engineering, ${ }^{2}$ SRF at AICRP on PHET, Dr.PDKV Akola \\ ${ }^{3}$ Department of Agricultural Process Engineering, College of Agricultural Engineering and \\ Technology, Vasantrao Naik Marathwada Krishi Vidyapeeth Parbhani, India \\ *Corresponding author
}

\section{A B S T R A C T}

Keywords

Sorghum, Hardness, Yield

Article Info

Accepted:

15 December 2019

Available Online:

20 January 2020
Sorghum popps were developed with high temperature short time (HTST) popping process. The effect of process parameters viz. Soaking time (ST), Conditioning time (CT) and Popping temperature (PT) on the product quality was investigated by conducting experiments using Box Behnken Design (BBD). Linear and quadratic models were developed using response surface methodology (RSM) to study the synergy between process parameters and responses in terms of popping yield (PY), expansion ratio (ER), crispness (Csp), hardness (HRD) and colour L* value. The optimal product quality were obtained at the optimal process condition as Popping temperature at $260{ }^{\circ} \mathrm{C}$ followed by Soaking time $\left(80^{\circ} \mathrm{C}, 2 \mathrm{~min}\right)$ and Conditioning time $3 \mathrm{~h}$ having popping yield (85.64\%), expansion ratio (15.17), crispness $(11+$ peaks $)$, hardness $(17 \mathrm{~N})$ and colour $\mathrm{L}^{*}$ value (75.61).

\section{Introduction}

Sorghum (Sorghum bicolor) popularly called as jowar, is the king of millets and is the fifth in importance among the world's cereals, after wheat, rice, maize and barley. The nutrient composition of sorghum grain indicates that it is a good source of energy, protein, vitamins, and minerals including trace elements. Sorghum has 11.9 per cent of moisture and about 10.4 per cent of protein and a lower fat content of 1.9 percent. The fibre and mineral content of grain sorghum is 1.6 per cent. It provides about $349 \mathrm{k}$ cal and gives 72.6 per cent of carbohydrates. Over the years, the popping have been applied to many cereals including, rice, wheat, corn, amaranth seed (Mariotti et al., 2005), wheat (Yengi et al., 2004 and Pardesi et al., 2009). Sorghum is the only one that can contain significant amounts 
of starch granules in the mesocarp cells. The starch-devoid germ is rich in fat, soluble sugars and proteins (albumins and globulins) whereas the endosperm is divided into the single layered aleuronic and the starchy endosperm cells positioned in the corneous and floury or chalky regions of the endosperm (Sergio et al., 2012).

Starch content of sorghum range between 64.2 to 70.6 per cent (Miller and Burns, 1970). In popping process the starchy food stuff is expanded with sudden application of heat at atmospheric pressure or by sudden pressure drop in high pressure chamber at high temperature (Matz, 1970).

Temperature of air, puffing time and initial moisture content of the material are important factors in hot air puffing (Pardeshi and Chattopadhyay, 2010; Pardeshi and Chattopadhyay, 2014). A few reports available on popping of sorghum revealed that, sorghum expands very well when subjected to high temperature and short time (HTST) treatment.

Popping imparts acceptable taste and desirable aroma to pop sorghum. Popping being a dry heat process may inactivate the lipase and improve the shelf life of popped products. Popped sorghum being a pre-cooked ready to eat material can be used in snack foods, specialty foods as a base for development of supplementary foods (Sharma et al., 2014).

However, detailed investigations are needed to determine the quality of popped sorghum and its suitability for different food uses. Present study was undertaken to develop popped product from sorghum grains and optimize the process parameters using Soaking time (ST), Conditioning time (CT), Popping temperature (PT). For this purpose, Box Behnken Design (BBD) and response surface methodology (RSM) were used to fit a liner and second order polynomial by a least square technique.

\section{Materials and Methods}

\section{Preparation of Sorghum popps}

The Sorghum grain was purchased from local market. The soaking was carried out at $80{ }^{\circ} \mathrm{C}$ temperature of water for $2 \mathrm{~min}$, conditioning was carried out at $3 \mathrm{~h}$ and popping was carried out by using multigrain popping and puffing (HTST) machine at $260{ }^{\circ} \mathrm{C}$ and 3 RPM. This machine has rotating drum and digital temperature controlled panel. The following quality characteristics are optimized by using RSM.

\section{Popping yield (\%)}

It is the ratio of total weight of popped sample to the sum of total weight of popped and unpopped grains.

Popping yield

$=$ Total weight of popped grains

--------------------------------------X 100

Total weight of popped grains + wt. of unpopped grains

\section{Expansion Ratio}

The expansion ratio (ER) for all the samples was determined in terms of ratio of average bulk volume (vp) of puffed product during puffing to the average initial bulk volume (vi) (Chandrasekhar and Chattopadhyay, 1990) of product before introducing in

Expansion ratio

$=$ Total $\mathrm{popped} /$ puffed volume $(\mathrm{cm} 3)$

Volume of raw kernels (cm3)

\section{Color}

Color ( $\mathrm{L}^{*}$ value) of the popped products was determined by using Hunter Lab colorimeter. Color measurements were conducted after 2 
days of production of products. Before testing the sample, the instrument was calibrated with standard black and white tiles supplied with the instrument. The color readings were expressed in terms of $\mathrm{L}^{*}$ value. The $\mathrm{L}^{*}$ value represents the light-dark spectrum with range of 0 (black) to 100 (white).

\section{Textural Measurement (Hardness and Crispness)}

The texture characteristics of popped sorghum in terms of hardness and crispness were measured using a Stable Micro System TAXT2 texture analyser (Texture Technologies Corp., UK), fitted with a $2.5 \mathrm{~mm}$ diameter circular punch. The studies were conducted at a pre test speed of $1 \mathrm{~mm} / \mathrm{s}$, test speed of 1 $\mathrm{mm} / \mathrm{s}$, distance of $50 \%$ strain, and load cell of $5.0 \mathrm{~kg}$. Hardness value was considered as mean peak compression force and expressed in grams and crispness was measured in terms of major positive peaks (Cruzycelis, et al., 1996; Anon., 1998) with the help of Texture Analyser. For measurement of crispness a macro was developed which counts number of major peaks represented in the force-time deformation curve during compression (Nath and Chattopadhyay, 2007). The compression force at which product offers maximum resistance at the highest peak of graph was taken as the hardness value for that sample. Average of 10 replications was taken for both the parameters in each individual experiment.

\section{Experimental Design for Sorghum popps}

In the present study, the process variables considered were soaking time ( 1 to $3 \mathrm{~min}$ at $\left.80{ }^{\circ} \mathrm{C}\right)$, conditioning time $(2$ to $4 \mathrm{~h}$ ) and popping temperature $\left(240\right.$ to $\left.280{ }^{\circ} \mathrm{C}\right)$. The experimental design was applied after selection of the ranges. Seventeen experiments were performed according to a Box Behnken Design (BBD) with three variables and three levels of each variable. Table 1 gives the levels of variables in coded and actual units, and Table 2 indicates the treatment combinations of variable levels used in the BBD. The central point in the design was repeated five times to calculate the reproducibility of the method (Montgomery, 2001). In Table 1, the coded levels of process variables are fixed as given below (Myers, 1971). The HTST popping experiments were conducted according to the BBD design (Table 1) and RSM were applied to the experimental data using a commercial statistical package, Design Expert - version 10.0 (Stat Ease, 2002). The relative effect of the process variables (Soaking time (ST), Conditioning time (CT), Popping temperature (PT)) on the responses was studied and the popping process was optimized in order to get best quality popped sorghum based ready-toeat snacks. The responses studied were final popping yield (PY) (\%), Expansion ratio (ER), Hardness (HD), crispness (CSP, no. of +ve peaks) and colour $\mathrm{L}^{*}$ value. A second order polynomial equation of the following form was assumed to relate the response, $\mathrm{Y}$ and the factors, such as:

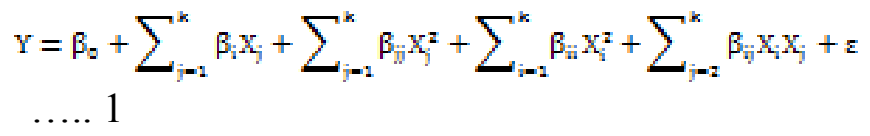

Where, $\mathrm{y}=$ predicted response, $\beta 0=\mathrm{a}$ constant, $\beta \mathrm{i}=$ linear coefficient, $\beta \mathrm{ii}=$ squared coefficient, $\beta \mathrm{ij}=$ interaction coefficient, $\mathrm{Xi}$ and $\mathrm{Xj}=$ the independent variables, $\varepsilon=$ noise or error.

\section{Data Analysis and Optimization}

Regression analysis and analysis of variance (ANOVA) were conducted for fitting the models Represented by Eq. (1) and to examine the statistical significance of the model terms. The adequacy of the models were determined by using model analysis, lack-of fit test and $\mathrm{R}^{2}$ (coefficient of determination) analysis as 
outlined by (Lee et al., 2000) and (Weng et al., 2001). The lack of fit is a measure of the failure of a model to represent data in the experimental domain at which points were not included in the regression or variations in the models cannot be accounted for by random error (Montgomery, 2001). If there is a significant lack of fit, as indicated by a low probability value, the response predictor is discarded. The $\mathrm{R}^{2}$ is defined as the ratio of the explained variation to the total variation and is a measure of the degree of fit (Haber and Runyon, 1977). Coefficient of variation (CV) indicates the relative dispersion of the experimental points from the prediction of the model. Response surfaces and contour plots were generated with the help of commercial statistical package, Design Expert - version 10.0 (Stat Ease, 2002). The numerical and graphical optimization was also performed by the same software.

\section{Numerical Optimization}

Numerical optimization technique of the Design-Expert software was used for simultaneous Optimization of the multiple responses. The desired goals for each factor and response were chosen. The goals may apply to either factors or responses. The possible goals are: maximize, minimize, target, within range and none (for responses only). All the independents factors were kept within range while the responses were either maximized or minimized. In order to search a solution optimizing multiple responses, the goals are combined into an overall composite function $\mathrm{D}(\mathrm{x})$, called the desirability function (Myers and Montgomery, 2002). Desirability is an objective function that ranges from zero outside of the limits to one at the goal. It reflects the desirable ranges for each response. The desirable ranges are from zero to one (least to most desirable), respectively. The numerical optimization finds a point that maximizes the desirability function. The characteristics of a goal may be altered by adjusting the weight or importance (Stat Ease, 2002).

\section{Results and Discussion}

\section{Effect of Various Process Parameters on popping yield}

The popping yield of popped sorghum is a ratio of weight of popped grains to the weight of total sample of grain. The computed values for popping yield of popped sorghum prepared with different combination of process parameters are presented in Table 2 It was observed that the values of popping yield of popped sorghum were ranged $33.78 \%$ to $85.64 \%$ within the combination of variable studied. A second-order polynomial equation was used to fit the experimental data.

The quadratic equation describing the effect of the process parameters on popping yield of popped sorghum in terms of actual level of variables are given as:

$\mathrm{PY}(\%)=+85.50+7.87 \mathrm{X}_{1}+4.38 \mathrm{X}_{2}+$ $12.15 X_{3}-2.82 X_{1} X_{2}+2.57 X_{1} X_{3}+0.98$ $\mathrm{X}_{2} \mathrm{X}_{3}-\quad 20.33 \mathrm{X}_{1}^{2}-6.09 \mathrm{X}_{2}^{2}-26.76 \mathrm{X}_{3}^{2}$ Eq....... 2

Where, $\mathrm{X}_{1}=$ soaking time, $\mathrm{X}_{2}=$ Conditioning time and $\mathrm{X}_{3}=$ popping temperature

The comparative effect of each parameter on popping yield of popped sorghum was observed by the F-values in the Table 3 and also by the magnitude of coefficients of the process variables. Model F value 28.25 implies that model is significant at 5\% level. The lack of fit was showing Non-significant showing good model fit. The positive coefficients in case of first order term of soaking time $\left(\mathrm{X}_{1}\right)$, conditioning time $\left(\mathrm{X}_{2}\right)$ and popping temperatures $\left(\mathrm{X}_{3}\right)$ Indicated that increase in popping yield with increase of 
these parameters while negative coefficients of their quadratic term suggested that excessive increase of these parameters resulted in decrease of popping yield. The effect of Popping temperature $\left(\mathrm{X}_{3}\right)$ was most prominent on popping yield followed by soaking time $\left(\mathrm{X}_{1}\right)$ and conditioning time $\left(\mathrm{X}_{3}\right)$.

Through Fig. 1 it was clear that, popping yield of popped sorghum increased with increase in soaking time $\left(\mathrm{X}_{1}\right)$ of raw sorghum up to $2 \mathrm{~min}$, conditioning of soaked sorghum $\left(\mathrm{X}_{2}\right)$ up to 3 $\mathrm{hr}$ and popping temperature $\left(\mathrm{X}_{3}\right)$ at $260{ }^{\circ} \mathrm{C}$ respectively, further popping yield value of popped sorghum decreased at higher levels of these process parameters.

\section{Effect of process parameter on expansion ratio (ER)}

The expansion ratio of popped sorghum is a ratio of volume of popped grains to the volume of initial sample of grains. The computed values for expansion ratio of popped sorghum prepared with different combination of process parameters are presented in Table 2. It was observed that the values of expansion ratio of popped sorghum were ranged 4.17 to 15.19 within the combination of variable studied. The quadratic equation describing the effect of the process parameters on expansion ratio of popped sorghum in terms of actual level of variables are given as:

$\mathrm{ER}=+15.15+0.9288 \mathrm{X}_{1}+1.74 \mathrm{X}_{2}+2.74 \mathrm{X}_{3}-$ $0.4750 \mathrm{X}_{1} \mathrm{X}_{2}-0.06 \mathrm{X}_{1} \mathrm{X}_{3}-0.43 \mathrm{X}_{2} \mathrm{X}_{3}-$ $2.12 \mathrm{X}_{1}^{2}-1.36 \mathrm{X}_{2}^{2}-3.83 \mathrm{X}_{3}^{2} \mathrm{Eqn}$

Where, $X_{1}=$ soaking time, $X_{2}=$ conditioning time and $X_{3}=$ popping temperature

The comparative effect of each factor of each parameter on the expansion ratio was observed by the F value in the ANOVA and also by the magnitude of coefficients of the process variable as shown in the Table 3. Model F value 111.92 implies that the model is significant at $5 \%$ level. The lack of fit $F$ value was non-significant showing good model fit. The positive coefficients in case of first order term of soaking time, conditioning time and popping temperatures indicated that increase in expansion ratio with increase of these parameters while negative coefficients of their quadratic term suggested that excessive increase of these parameters resulted in decrease of expansion ratio. Effect of popping temperature $\left(\mathrm{X}_{3}\right)$ was most prominent among the first order terms followed by conditioning time $\left(\mathrm{X}_{2}\right)$ and soaking time $\left(\mathrm{X}_{1}\right)$.

Through Fig. 2 it was clear that, expansion ratio of popped sorghum increased with increase in soaking time $\left(\mathrm{X}_{1}\right)$ of raw sorghum up to $2 \mathrm{~min}$ in hot water $\left(80^{\circ} \mathrm{C}\right)$, conditioning of soaked sorghum $\left(\mathrm{X}_{2}\right)$ up to $3 \mathrm{hr}$ and popping temperature $\left(\mathrm{X}_{3}\right)$ at $260{ }^{\circ} \mathrm{C}$ respectively, further expansion ratio value of popped sorghum decreased at higher levels of these process parameters.

\section{Effect of process parameter on crispiness}

The computed values for crispiness of popped sorghum prepared with different combination of process parameters are presented in Table 2. It was observed that the values of crispiness of popped sorghum were ranged 4 to 11 within the combination of variable studied. A secondorder polynomial equation was used to fit the experimental data.

The quadratic equation describing the effect of the process parameters on crispiness of popped sorghum in terms of actual level of variables are given as:

$\mathrm{CRS}=+10.80+0.89 \mathrm{X}_{1}+1.12 \mathrm{X}_{2}+2.37 \mathrm{X}_{3}-$ $0.25 \mathrm{X}_{1} \mathrm{X}_{2}-0.25 \mathrm{X}_{1} \mathrm{X}_{3}+0.000 \mathrm{X}_{2} \mathrm{X}_{3}-1.90$ $\mathrm{X}_{1}^{2}-2.15 \mathrm{X}_{2}^{2}-4.155 \mathrm{X}_{3}^{2}$ Eqn ...... 4

Where, $\mathrm{X}_{1}=$ soaking time, $\mathrm{X}_{2}=$ Conditioning 
time and $\mathrm{X}_{3}=$ popping temperature

The comparative effect of each factor on crispiness was observed by the F-values in the analysis of variance (Table 3 ) and also by the magnitude of coefficients of the process variables. The ANOVA data shows a model $\mathrm{F}$ value of 30.57 which is significant at $5 \%$ level. The lack of fit $\mathrm{F}$ value is non-significant showing good fit of model. The positive coefficients in case of first order term of soaking time $\left(\mathrm{X}_{1}\right)$, conditioning time $\left(\mathrm{X}_{2}\right)$ and popping temperatures (X3) indicated that increase in crispiness with increase of these parameters while negative coefficients of their quadratic term suggested that excessive increase of these parameters resulted in decrease of crispiness value. Effect of popping temperature $\left(\mathrm{X}_{3}\right)$ was most prominent on crispiness of popped sorghum followed by conditioning time $\left(\mathrm{X}_{2}\right)$ and soaking time $\left(\mathrm{X}_{1}\right)$.

Through Fig. 3 it was clear that, crispiness of popped sorghum increased with increase in soaking time $\left(\mathrm{X}_{1}\right)$ of raw sorghum up to $2 \mathrm{~min}$ in hot water at $\left(80^{\circ} \mathrm{C}\right)$, conditioning of soaked sorghum $\left(\mathrm{X}_{2}\right)$ up to $3 \mathrm{hr}$ and popping temperature $\left(\mathrm{X}_{3}\right)$ at $260{ }^{\circ} \mathrm{C}$ respectively, further crispiness value of popped sorghum decreased at higher levels of these process parameters.

\section{Effect of process parameter on Hardness}

Hardness of the popped sorghum was measured for different combinations of process parameters by using TA.XT-2 Texture Analyser as per the experimental design and presented in Table 2. It varied between 12 to $29 \mathrm{~N}$ within the combination of variable studied. Second order polynomial model was fitted adequately to the observed data with high coefficient of correlation $\left(\mathrm{R}^{2}=0.997\right)$.

This indicated that all the observed variation could be satisfactorily explained by the model.
The quadratic equation describing the effect of the process parameters on hardness of popped sorghum in terms of actual level of variables are given as:

$\mathrm{HRD}=+16.80-4.87 \mathrm{X} 1-2.12 \mathrm{X} 2+9.00 \mathrm{X} 3+$ $0.50 \times 1 \times 2+0.75 \times 1 \times 3+0.75 \times 2 \times 3-$ $0.85 \times 12+0.85 \times 22+2.10 \times 32$ Eqn..... 5

Where, $\mathrm{X}_{1}=$ soaking time, $\mathrm{X}_{2}=$ Conditioning time and $\mathrm{X}_{3}=$ popping temperature

The comparative effect of each factor on hardness could be observed by the F-values in the analysis of variance (Table 3 ) and also by the magnitude of coefficients of the coded variables. The ANOVA data shows a model $\mathrm{F}$ value of 232.11 which is significant at $5 \%$ level. The lack of fit $\mathrm{F}$ value is non-significant showing good fit of model.

The negative coefficient of the first order terms in the equation with actual variables indicated that, the hardness of popped sorghum decreased with increase in soaking time $\left(\mathrm{X}_{1}\right)$ of raw sorghum, conditioning time $\left(\mathrm{X}_{2}\right)$ of soaked sorghum and popping temperature $\left(\mathrm{X}_{3}\right)$. It was observed that popping temperature $\left(\mathrm{X}_{3}\right)$ had maximum influence on hardness followed by soaking time $\left(\mathrm{X}_{1}\right)$ and conditioning time $\left(\mathrm{X}_{2}\right)$.

Through Fig. 3 revealed that, the hardness of popped sorghum was decreased with an increase in soaking time of raw sorghum $\left(\mathrm{X}_{1}\right)$ up to $2 \mathrm{~min}$ in hot water $\left(80{ }^{\circ} \mathrm{C}\right)$, conditioning of soaked sorghum $\left(\mathrm{X}_{2}\right)$ up to $3 \mathrm{~h}$, it is also clear that, hardness of popped sorghum was decreased with an increase in levels of popping temperature $\left(\mathrm{X}_{3}\right) \quad 260{ }^{\circ} \mathrm{C}$, respectively. Further hardness of popped sorghum increased at higher levels of these process parameters. Hardness of popped sorghum decreases initially. This might be due to the fact that, combine effect of process variables on hardness of popped sorghum. 
Table.1 Levels, codes and intervals of variation for popping process

\begin{tabular}{|c|c|c|c|c|c|c|c|}
\hline $\begin{array}{c}\text { Sr. } \\
\text { No. }\end{array}$ & $\begin{array}{c}\text { Name of process } \\
\text { variable }\end{array}$ & Range & $\begin{array}{c}\text { Code } \\
(\mathbf{X i})\end{array}$ & -1 & 0 & +1 & $\begin{array}{c}\text { LEVELS } \\
\text { variation }\end{array}$ \\
\hline $\mathbf{1}$ & Soaking time (min) & $1-3$ & $\mathrm{X}_{1}$ & 1 & 2 & 3 & 1 \\
\hline $\mathbf{2}$ & $\begin{array}{c}\text { Conditioning time } \\
(\mathrm{h})\end{array}$ & $2-4 \mathrm{~h}$ & $\mathrm{X}_{2}$ & 2 & 3 & 4 & 1 \\
\hline $\mathbf{3}$ & $\begin{array}{c}\text { Popping temperature } \\
\left({ }^{\circ} \mathrm{C}\right)\end{array}$ & $240-280$ & $\mathrm{X}_{3}$ & 240 & 260 & 280 & 20 \\
\hline
\end{tabular}

Table.2 Experimental design (3 factors, 3 levels) and corresponding values of responses (quality parameters) obtained during popping of sorghum

\begin{tabular}{|c|c|c|c|c|c|c|c|c|}
\hline \multirow[b]{2}{*}{ Treatments } & \multirow[b]{2}{*}{$X_{1}$} & \multirow[b]{2}{*}{$\mathrm{X}_{2}$} & \multirow[b]{2}{*}{$\mathrm{X}_{3}$} & \multicolumn{5}{|c|}{ Quality characteristics } \\
\hline & & & & $\begin{array}{l}\text { Popping } \\
\text { yield } \\
(\%)\end{array}$ & $\begin{array}{l}\text { Expansion } \\
\text { ratio }\end{array}$ & $\begin{array}{c}\text { Crispiness } \\
\text { (+ve } \\
\text { peaks) }\end{array}$ & $\begin{array}{c}\text { Color } \\
\mathrm{L}^{*}\end{array}$ & $\begin{array}{l}\text { Hardness } \\
(\mathrm{N})\end{array}$ \\
\hline 1 & -1 & -1 & 0 & 47.16 & 9.53 & 7 & 73.32 & 22 \\
\hline 2 & 1 & -1 & 0 & 61.13 & 11.29 & 6 & 74.32 & 17 \\
\hline 3 & -1 & 1 & 0 & 62.67 & 12.54 & 8 & 72.39 & 19 \\
\hline 4 & 1 & 1 & 0 & 65.38 & 14.23 & 6 & 74.13 & 16 \\
\hline 5 & -1 & 0 & -1 & 36.43 & 4.17 & 4 & 65.34 & 29 \\
\hline 6 & 1 & 0 & -1 & 33.78 & 6.78 & 5 & 64.13 & 24 \\
\hline 7 & -1 & 0 & 1 & 48.65 & 10.64 & 5 & 50.93 & 14 \\
\hline 8 & 1 & 0 & 1 & 63.43 & 12.84 & 5 & 48.14 & 12 \\
\hline 9 & 0 & -1 & -1 & 56.43 & 4.23 & 4 & 65.86 & 29 \\
\hline 10 & 0 & 1 & -1 & 48.08 & 5.65 & 4 & 64.56 & 25 \\
\hline 11 & 0 & -1 & 1 & 65.76 & 10.94 & 5 & 48.59 & 13 \\
\hline 12 & 0 & 1 & 1 & 68.86 & 14.75 & 5 & 47.95 & 12 \\
\hline 13 & 0 & 0 & 0 & 85.59 & 14.34 & 11 & 75.23 & 17 \\
\hline 14 & 0 & 0 & 0 & 85.54 & 15.17 & 11 & 75.98 & 17 \\
\hline 15 & 0 & 0 & 0 & 85.32 & 15.13 & 11 & 75.45 & 16 \\
\hline 16 & 0 & 0 & 0 & 85.43 & 15.19 & 10 & 73.14 & 17 \\
\hline 17 & 0 & 0 & 0 & 85.64 & 15.17 & 11 & 75.61 & 17 \\
\hline
\end{tabular}

$\mathrm{X}_{1}=$ soaking time, $\mathrm{X}_{2}=$ Conditioning time and $\mathrm{X}_{3}=$ popping temperature 
Table.3 Analysis of variance showing the effect of process parameters on popping yield, expansion ratio, crispiness, hardness and colour $\mathrm{L}^{*}$ value of popped sorghum

\begin{tabular}{|c|c|c|c|c|c|}
\hline \multirow{2}{*}{ Source } & \multicolumn{5}{|c|}{ F-value } \\
\cline { 2 - 6 } & PY & ER & CRP & HDS & L $^{*}$ \\
\hline Model & $28.25^{*}$ & $111.92^{*}$ & $30.57^{*}$ & $232.11^{*}$ & $114.88^{*}$ \\
\hline $\mathbf{X}_{\mathbf{1}}$-soaking time & 14.47 & 24.64 & 1.15 & 127.02 & 1.11308 \\
\hline $\begin{array}{c}\mathbf{X}_{\mathbf{2}} \text {-conditioning } \\
\text { time }\end{array}$ & 5.71 & 48.01 & 2.2869 & 45.73 & 1.6666 \\
\hline $\mathbf{X}_{\mathbf{3} \text {-popping temp }}$ & 27.78 & 377.89 & 7.58 & 170.32 & 294.17 \\
\hline $\mathbf{X}_{\mathbf{1}} \mathbf{X}_{\mathbf{2}}$ & 2.06 & 0.0045 & 0.5738 & 4.52 & 0.0780 \\
\hline $\mathbf{X}_{\mathbf{1}} \mathbf{X}_{\mathbf{3}}$ & 0.2581 & 2.46 & 0.5738 & 10.16 & 0.3555 \\
\hline $\mathbf{X}_{\mathbf{2}} \mathbf{X}_{\mathbf{3}}$ & 2.13 & 0.3448 & 0.0000 & 10.16 & 0.0620 \\
\hline $\mathbf{X}_{\mathbf{1}}$ & 89.76 & 33.78 & 34.89 & 13.74 & 0.7888 \\
\hline $\mathbf{X}_{\mathbf{2}}$ & 14.47 & 41.53 & 44.67 & 13.74 & 2.25 \\
\hline $\mathbf{X}_{\mathbf{3}}$ & 82.98 & 426.24 & 166.43 & 83.86 & 723.85 \\
\hline Lack of Fit & $6.04^{\mathrm{NS}}$ & $3.28^{\mathrm{NS}}$ & $3.75^{\mathrm{NS}}$ & $1.25^{\mathrm{NS}}$ & $1.93^{\mathrm{NS}}$ \\
\hline
\end{tabular}

PY- popping yield, ER- expansion ratio, CRP- crispiness, HDS- hardness L*- colour value * - significant, NS- Non-significant

Fig.1 Effect of $\left(X_{1}\right)$ and $\left(X_{3}\right)$ at constant $\left(X_{2}\right)(A)$ and effect of $\left(X_{2}\right)$ and $\left(X_{3}\right)$ at constant $\left(X_{1}\right)(B)$ on popping yield of popped sorghum

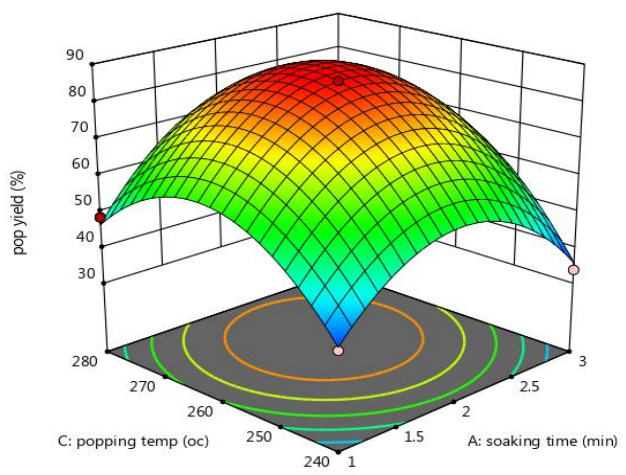

(A)

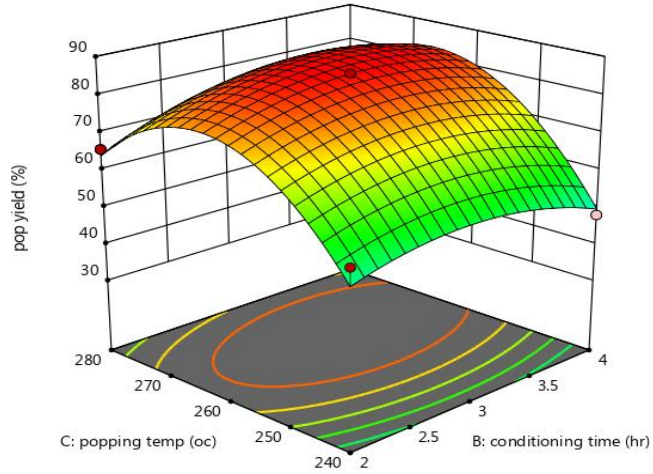

(B) 
Fig.2 Effect of $\left(X_{1}\right)$ and $\left(X_{3}\right)$ at constant $\left(X_{2}\right)(A)$ and effect of $\left(X_{2}\right)$ and $\left(X_{3}\right)$ at constant $\left(X_{1}\right)(B)$ on expansion ratio of popped sorghum

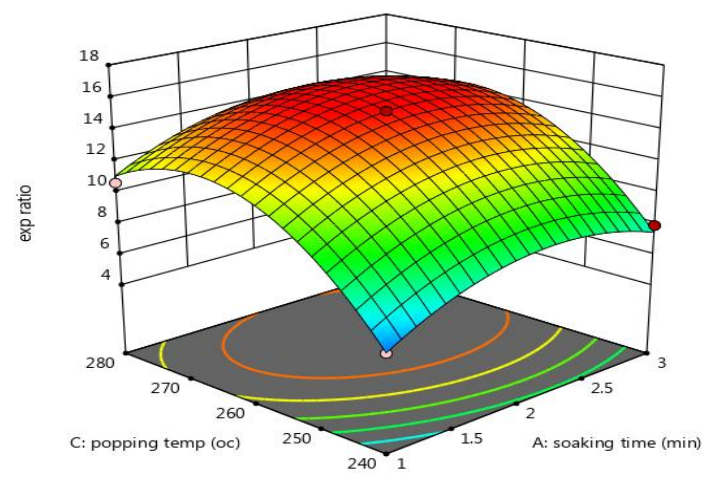

(A)

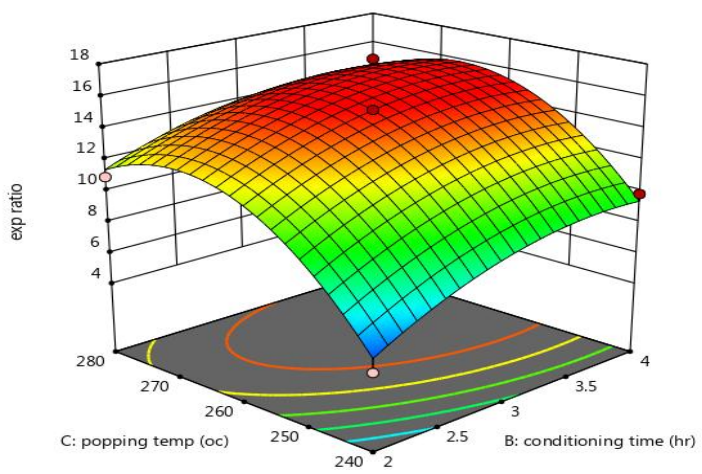

(B)

Fig.3 Effect of $\left(X_{1}\right)$ and $\left(X_{3}\right)$ at constant $\left(X_{2}\right)(A)$ and effect of $\left(X_{2}\right)$ and $\left(X_{3}\right)$ at constant $\left(X_{1}\right)(B)$ on crispiness of popped sorghum

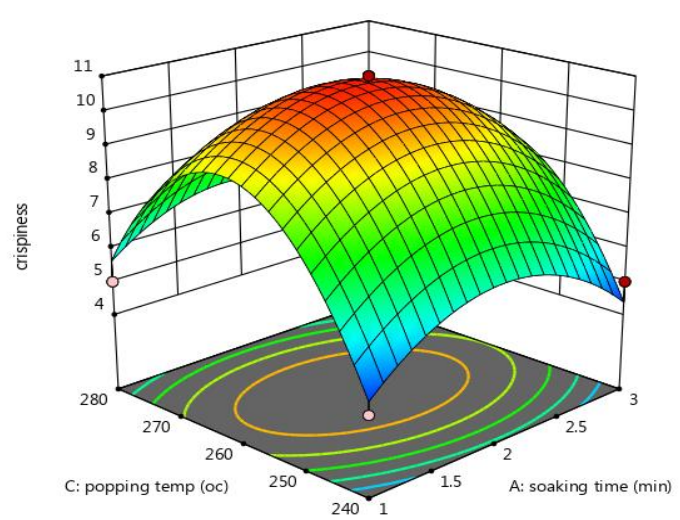

(A)

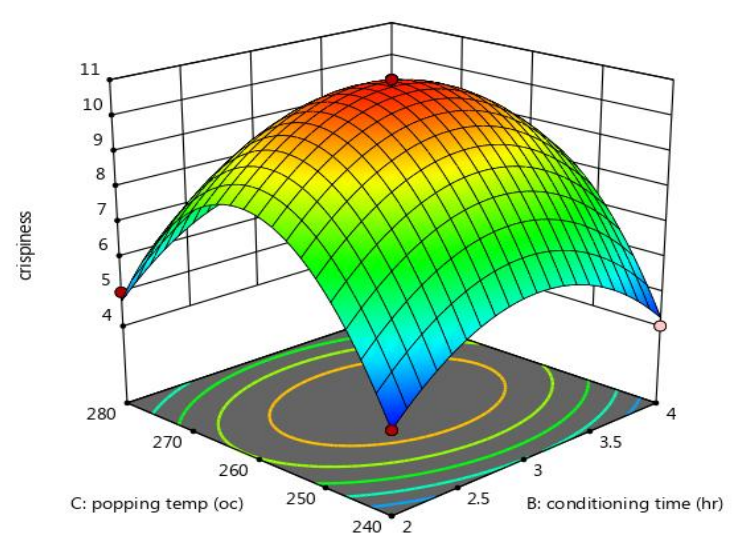

(B) 
Fig.4 Effect of $\left(\mathrm{X}_{1}\right)$ and $\left(\mathrm{X}_{3}\right)$ at constant $\left(\mathrm{X}_{2}\right)(\mathrm{A})$ and effect of $\left(\mathrm{X}_{2}\right)$ and $\left(\mathrm{X}_{3}\right)$ at constant $\left(\mathrm{X}_{1}\right)(\mathrm{B})$ on hardness of popped sorghum

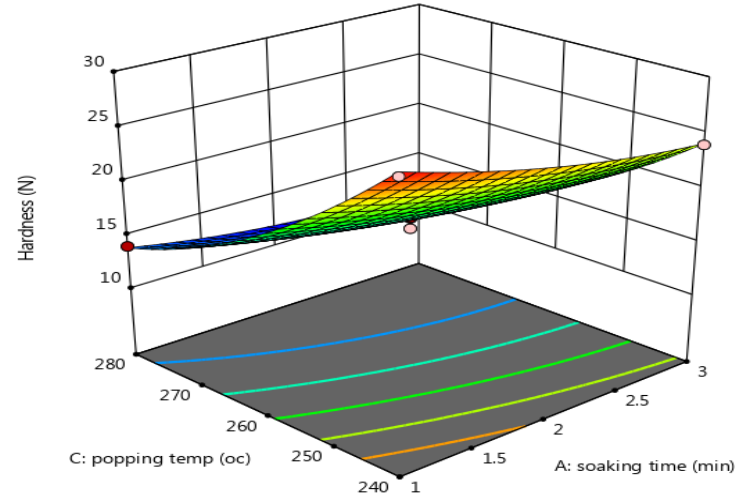

(A)

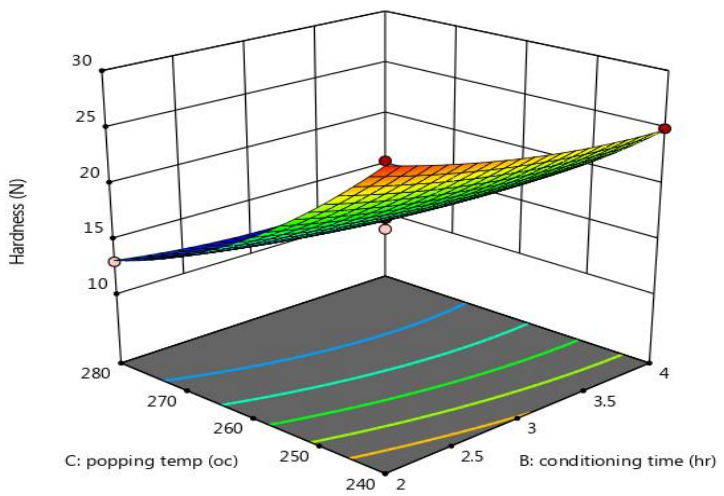

(B)

Fig.5 Effect of $\left(\mathrm{X}_{1}\right)$ and $\left(\mathrm{X}_{3}\right)$ at constant $\left(\mathrm{X}_{2}\right)(\mathrm{A})$ and effect of $\left(\mathrm{X}_{2}\right)$ and $\left(\mathrm{X}_{3}\right)$ at constant $\left(\mathrm{X}_{1}\right)(\mathrm{B})$ on colour $\mathrm{L}^{*}$ value of popped sorghum

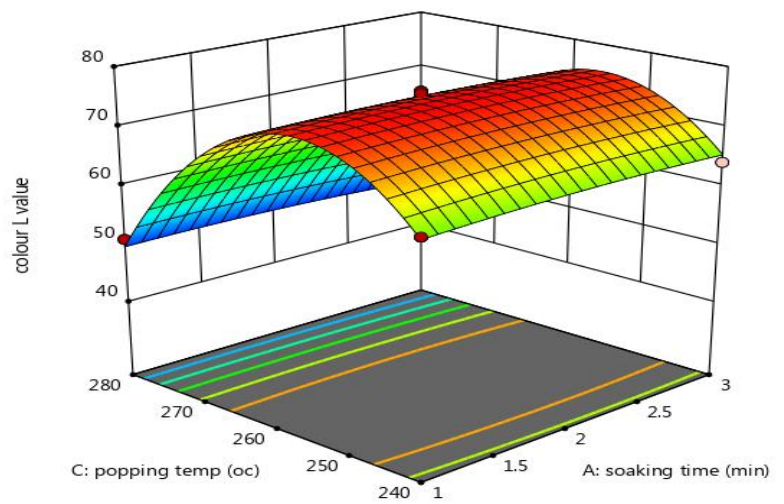

(A)

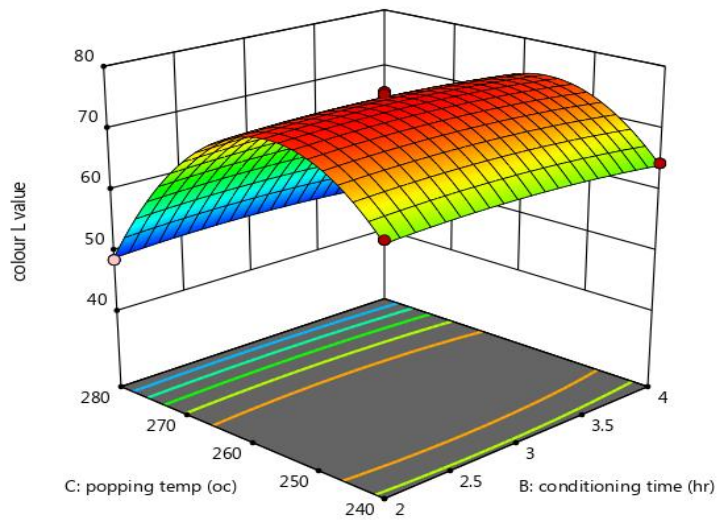

(B) 
Fig.6 ( $a$ and b) Overlay plot showing predicted values of quality characteristics of popped sorghum

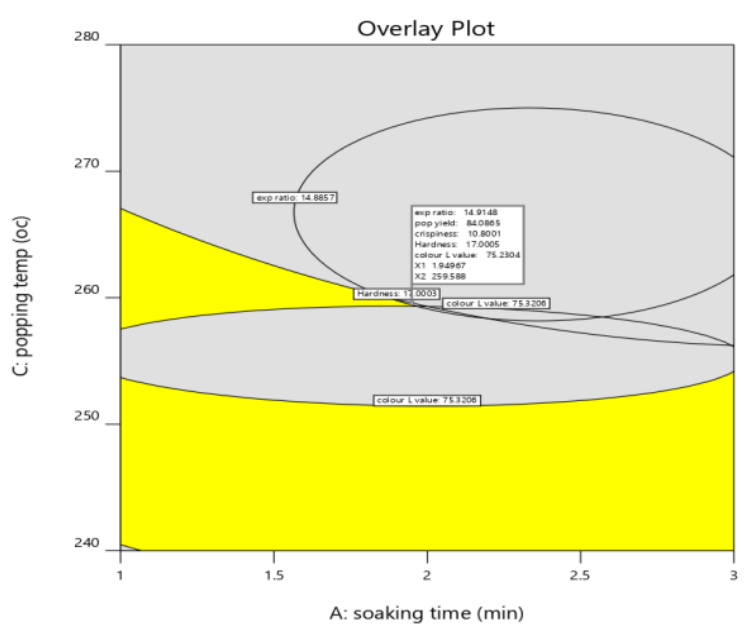

Effect of process parameter on color $(\mathrm{L}$ value) of popped sorghum

The colour of popped sorghum prepared by varying various process parameters was determined by Colour Flex Hunter Lab Colorimeter in terms of ( $\mathrm{L}^{*}$ value). Colour indicates the lightness of popped sorghum. The measured values for colour of popped sorghum prepared with different combination of process parameters are presented in Table 2. It was observed that the values of colour of popped sorghum were ranged 47.95 to 75.98 within the combination of variable studied.

The quadratic equation describing the effect of the process parameters on $L^{*}$ value of popped sorghum in terms of actual level of variables is given as:

CLR $=75.08-1.15 \mathrm{X}_{1}-1.78 \mathrm{X}_{2}-12.04 \mathrm{X}_{3}+$ $0.18 \mathrm{X}_{1} \mathrm{X}_{2}-0.39 \mathrm{X}_{1} \mathrm{X}_{3}+4.17 \mathrm{X}_{2} \mathrm{X}_{3}-0.57 \mathrm{X}_{1}^{2}-$ $0.96 \mathrm{X}_{2}{ }^{2}-17.37 \mathrm{X}_{3}{ }^{2} \mathrm{Eqn} \ldots 6$

Where, $X_{1}=$ soaking time, $X_{1}=$ surface drying time and $X_{1}=$ puffing temperature

The comparative effect of each factor on color ( $\mathrm{L}^{*}$ value) could be observed by the F-values

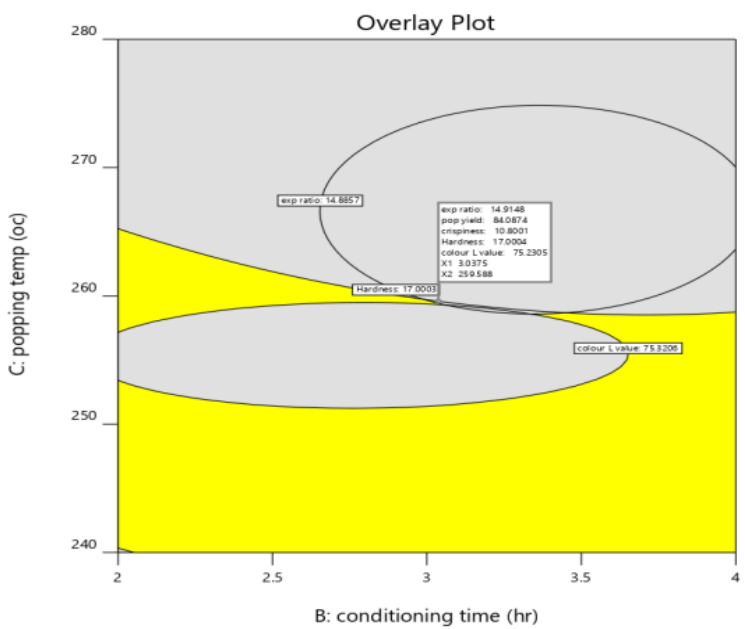

in the analysis of variance Table 3. The ANOVA data shows a model $\mathrm{F}$ value of 114.88 which is significant at $5 \%$ level. The lack of fit $\mathrm{F}$ value is non-significant showing good fit of model.

The negative coefficients of the first order terms with the equation of coded variables indicated that, the colour $\mathrm{L}^{*}$ value of popped sorghum decreased with increase in soaking time $\left(\mathrm{X}_{1}\right)$, conditioning time $\left(\mathrm{X}_{2}\right)$ and popping temperature $\left(\mathrm{X}_{3}\right)$. While negative coefficients of their interaction and quadratic term suggested that excessive increase of these parameters resulted in decrease of lightness of popped sorghum. It was observed that popping temperature $\left(\mathrm{X}_{3}\right)$ had maximum influence on lightness followed by conditioning time $\left(\mathrm{X}_{2}\right)$ and soaking time $\left(\mathrm{X}_{1}\right)$.

\section{Optimization}

To perform this operation, Design-Expert program (Version 10.0) of the STAT-EASE software (Stat Ease, 2002), was used for simultaneous optimization of the multiple responses. The software generated ten optimum conditions of independent variables with the predicted values of responses. In Fig 
6 shows the superimposed contours for PY, ER, HD, CSP (+ve peaks) and colour L* value for popping of sorghum grains based at varying ST, CT and PT.

The optimum values of process variables obtained by numerical optimization as follows:

$\begin{array}{lll}\text { Soaking time (min) } & : & 2 \\ \text { Conditioning time }(\mathrm{h}): & 3 \\ \text { popping temperature }\left({ }^{\circ} \mathrm{C}\right): & 260 \\ \text { Popping yield (\%) } \quad: & 84.08 \\ \text { Expansion ratio } \quad: & 14.91 \\ \text { Crispiness } & : & 10 \\ \text { Hardness (N) } & : & 15.93 \\ \text { Colour } \mathrm{L}^{*} \text { value } & : & 73.98\end{array}$

The optimization technique of BBD and RSM were used in design of experiments and optimization successfully exhibited the effect of process parameters (ST, CT and PT) on the responses (PY, ER, HD, CSP and $\mathrm{L}^{*}$ value) of the popped sorghum. The optimal popping of sorghum grains at $260{ }^{\circ} \mathrm{C}$ followed by soaking time $2 \mathrm{~min}\left(80{ }^{\circ} \mathrm{C}\right)$ and conditioning time $3 \mathrm{~h}$. The popped sorghum product at the optimal process condition having popping yield (85.64 $\%)$, expansion ratio (15.17), crispness $(11+$ peaks), hardness $(17 \mathrm{~N})$ and colour $\mathrm{L}^{*}$ value (75.61).

\section{References}

Anonymous (1998). Comparison of textural qualities of crisp samples by bulk compression using an Ottawa cell. TAXT2 Application study, Stable Micro Systems Ltd.
Chandrasekhar PR and Chattopadhyay PK (1990). Heat transfer during fluidized bed puffing of rice grains. Journal of Food Process Engineering, 11: 147157.

Cruzycelis LP, Rooney LW and McDonough CM (1996). A ready-to-eat breakfast cereal from food-grade sorghum. Cereal Chemistry, 73(1): 108-114.

Haber A and Runyon R (1977). General Statistics, 3rd Edn. Reading, MA: Addison-Wesley Publishing Company.

Lee J., Ye L., Landen WO and Eitenmiller RR (2000). Optimization of an extraction procedure for the quantification of vitamin $\mathrm{E}$ in tomato and broccoli using response surface methodology. Journal of Food Composition and Analysis, 13: 45-57.

Matz SA (1970). Chemistry and Technology of Cereals as Food and Feed. West Port CT: AVI Publishing Co. Inc., pp.135-142.

Miller H and Burns EE (1970). Starch characteristics of selected grain sorghums as related to human foods. Journal of Food Science, 35: 666-668.

Myers RH (1971). Response Surface Methodology. Boston: Allyn and Bacon, Inc, Reprint 1976, Ann Arbor, MI: Edwards Brothers.

Montgomery DC (2001). Design and analysis of experiments (5th edition). New York: John Wiley., pp. 455-492.

Myers R and Montgomery DC (2002). Response Surface Methodology. New York, USA: Wiley.

Nath A. and Chattopadhyay P. K. (2007). Optimization of oven toasting for improving crispness and other quality attributes of ready to eat potato-soy snack using response surface methodology. Journal of Food Engineering, 80(4), 1282-1292.

Pardeshi I. L. (2009). Development of cereal based ready-to-eat snack foods, 
Unpublished Ph.D. Thesis, Post Harvest Technology Centre, IIT, Kharagpur (WB), India 721302.

Pardeshi IL and Chattopadhyay P. K. (2010). Hot air puffing kinetics for Soyfortified Wheat-based RTE snacks, Food and Bioprocess Technology, 3 (3): 415-426.

Pardeshi IL and Chattopadhyay PK (2014). Whirling Bed Hot Air Puffing Kinetics of Rice-Soy Ready-To-Eat (RTE) Snacks. Journal of Ready to Eat Food, 1(1): 01-10.

Stat-Ease Inc. (2002). Design Expert User's Guide, Design Expert Version 7.0, The
Stat-Ease Inc., MN, USA.

Sharma, V., Champawat, P.S. and Mudgal, V. D. (2014). Process development for puffing of sorghum. International journal of current research and academic review, 2(1):164-170.

Yenagi N. B. and Bhuvaneswari G. 2004. Cooking and popping qualities of raw and bulgurised wheat varieties. Research Highlights, JADU, 14:82186.

Weng W, Liu W and Lin W (2001). Studies on the optimum models of the dairy product. Asian- Australasian Journal of Animal Sciences, 14(10), 1470-1476

\section{How to cite this article:}

Kanifnath Nakade, Smita Khodke, Avinash Kakade and Nilza Othzes. 2020. Optimization of Process Technology for Popping of Sorghum. Int.J.Curr.Microbiol.App.Sci. 9(01): 180-192. doi: https://doi.org/10.20546/ijcmas.2020.901.021 